Article

\title{
Responses of Bats to Forest Fragmentation in the Mississippi River Alluvial Valley, Arkansas, USA
}

\author{
Rex E. Medlin, Jr. ${ }^{1,2, *}$, Matthew B. Connior ${ }^{3}$, Karen F. Gaines ${ }^{4}$ and Thomas S. Risch ${ }^{1}$
}

1 Department of Biological Sciences, Arkansas State University, State University, AR 72467, USA;

E-Mail: trisch@astate.edu

2 Department of Biology, Northwest Shoals Community College, Muscle Shoals, AL 35661, USA

3 Department of Biology, South Arkansas Community College, El Dorado, AR 71730, USA;

E-Mail: mconnior@southark.edu

4 Eastern Illinois University, Department of Biological Sciences, Charleston, IL 61920, USA;

E-Mail: kfgaines@eiu.edu

* Author to whom correspondence should be addressed; E-Mail: rexmedl @ aol.com;

Tel.: +1-256-331-5326, Fax: 1+256-331-5222.

Received: 18 August 2010; in revised form: 8 October 2010 / Accepted: 8 October 2010 /

Published: 12 October 2010

\begin{abstract}
Intense conversion of bottomland hardwood forests to rice and soybeans in the Mississippi River Valley of Arkansas has restricted the remaining forest to isolated fragments. Habitat fragmentation has proven to be detrimental to population sustainability of several species, and is the subject of intense study with often species and latitude specific responses. We compared both coarse land area classes and landscape fragmentation metrics from six $30 \mathrm{~km} \times 30 \mathrm{~km}$ subsets centered on publicly owned management areas to bat captures obtained from a 2005 population study. Patch density was the strongest predictor of total captures $\left(\mathrm{R}^{2}=0.801, \mathrm{p}=0.016\right)$ and of Myotis austroriparius captures $\left(\mathrm{R}^{2}=0.856, \mathrm{p}=0.008\right)$. Our findings indicate that patch density and area are important predictors of bottomland bat captures.
\end{abstract}

Keywords: bat; GIS; conservation; patch density; landscape ecology 


\section{Introduction}

Habitat associations of bats historically have been studied in the United States at the micro scale. Recent works at larger scales reveal interesting relationships [1-4], including a positive relationship between woodland fragments and bat activity at a $2 \mathrm{~km}$ scale [1]. In the Yucatan Peninsula, Montiel et al. [2] reported that species richness was similar between large and small fragments, but rate of capture was greater in large habitats than in smaller ones. In contrast, Cosson et al. [3] found fragmentation to result in a decrease in both abundance and richness of the bat community of French Guiana. Finally, a multi-scaled analysis in Paraguay revealed that the greatest number of significant bat responses occurred at the largest scale studied, with patch density and patch size negatively affecting species richness at the $5 \mathrm{~km}$ scale [4].

Fragmentation effects on bats in the Mississippi River Valley (MRV) are of interest because this area is the site of intensive fragmentation of bottomland hardwood forests by agriculture practices. Bottomland forests provide key ecological elements to bat species, including roosting sites [5-9] and foraging areas $[10,11]$. Prior to European settlement, the MRV consisted of ten million hectares of bottomland hardwood forests, but today less than half of the forest remains [12]. The largest portion of this loss $(87 \%)$ is attributed to conversion of bottomland forests to agriculture [13]. Of the hardwood forests remaining in the MRV, approximately 300,000 hectares or 19.0\% are in Arkansas [14]. The MRV of Arkansas is an ideal location to study fragmentation, as the remaining forests have similar microhabitat characteristics, are located in protected areas, and are isolated by a vast expanse of row crops $[15,16]$.

This manuscript represents a portion of a larger study on bottomland bats in Arkansas, which included a state-wide presence survey [17,18], an occupancy analysis [17], and a micro-habitat study [18]. This work is unique in scale of site replications, as the majority of landscape analyses have focused on smaller sized replicates (e.g., $1,500 \mathrm{~m}^{2}$ to $4 \mathrm{~km}^{2}$ [19]). Previous micro-habitat structures varied in their ability to explain distributions and species richness [16], prompting us to look for a more global explanation. Fragmentation metrics are good indicators of habitat use [20] and distribution [21] of bat species. We examined the effects of fragmentation on the abundance and species richness of bat populations in Northeastern Arkansas, including two rare species: Rafinesque's big-eared bat (Corynorhinus rafinesquii) and southeastern myotis (Myotis austroriparius).

\section{Methods}

\subsection{Study Area}

The study area (approximately $121 \mathrm{~km} \times 137 \mathrm{~km}$ in size) was located in the MRV of northeastern Arkansas near Jonesboro, and was composed of six landscapes (Figure 1) centered on Arkansas Game and Fish Wildlife Management Areas (Bayou De View WMA, Big Lake WMA, Black River NWR, Cache River WMA, St. Francis Sunken Lands WMA) and National Wildlife Refuges (Big Lake NWR, Wapanocca NWR). The habitats in these areas are bottomland hardwoods, typically bald cypress (Taxodium distichum) and water tupelo (Nyssa aquatica) swamps surrounded by oak (Quercus spp.)/hickory (Carya spp.) forests. For study purposes, Big Lake WMA and Big Lake NWR will be considered one unit due to their proximity (Figure 1B). 
Figure 1. State, regional, and management area maps of the six focal units (A-F) for a 2006 bottomland bat fragmentation analysis. The overall map is an Arkansas county map (www.basecampleasing.com) combined with a 1998 GAP 100 ha Grid landcover map (www.cast.uark.edu), whereas subsets are processed Landsat 7 satellite images (Univ. of AR 2002, Univ. of MA 2006). Map subsets are $30 \mathrm{~km} \times 30 \mathrm{~km}$, with forest indicated by the dark areas and agricultural or urban areas indicated by lighter tones. Mist-netting locations are indicated by white circles. (A) Bayou De View WMA, (B) Big Lake WMA, (C) Black River WMA, (D) Cache River NWR, (E) St. Francis Sunken Lands WMA, (F) Wapanocca NWR.
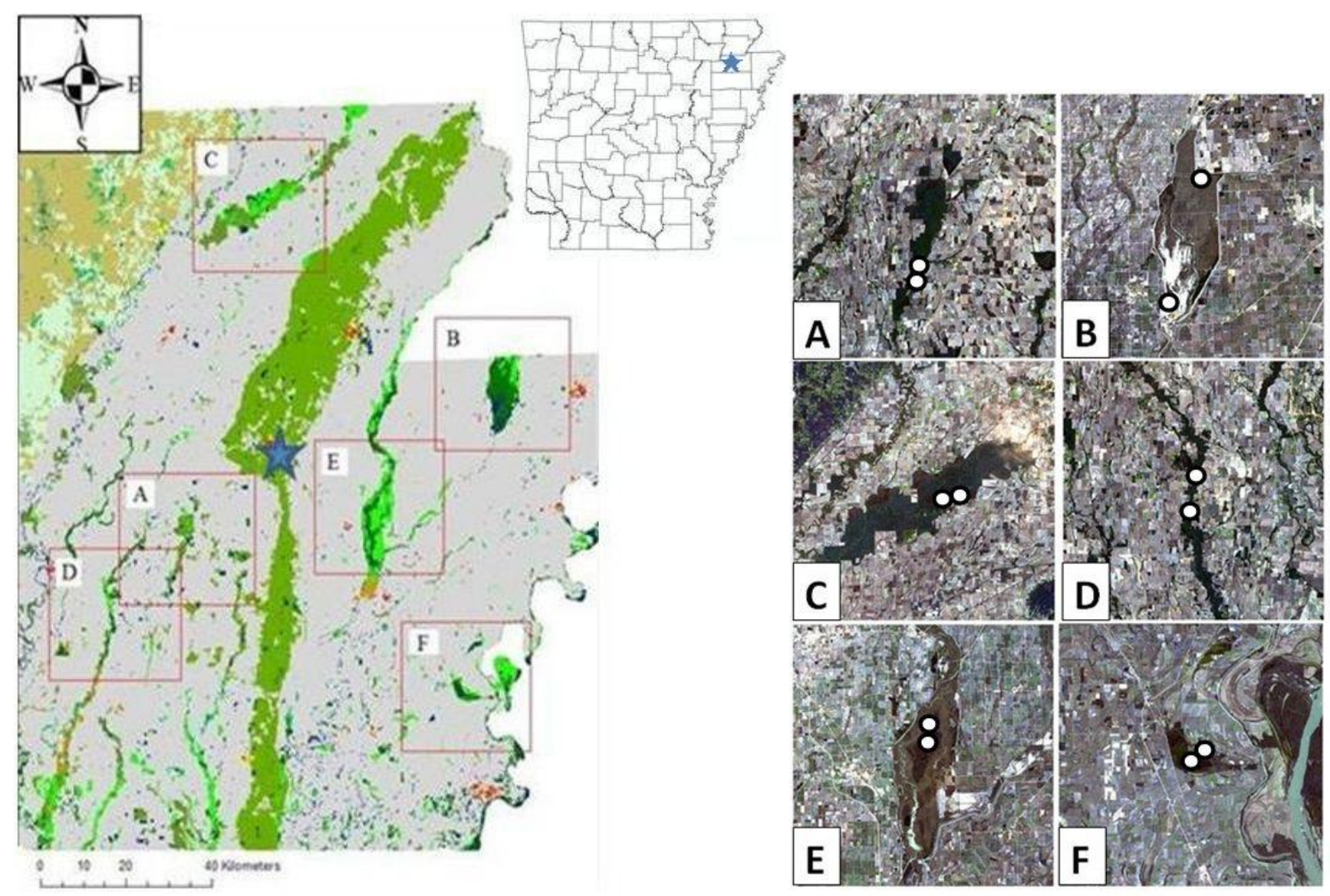

\subsection{Bat Capture Protocol}

Abundance and species richness data were obtained via mist-netting six management areas from 31 May to 29 June 2005. Trapping effort was divided between one land and one water corridor net site per management area. Areas were netted for two nights in succession for five hours each night beginning at dusk and lasting until approximately 1:00 A.M. CST. Each management area was surveyed for 12 nights total, six nights across a water corridor and six nights across a land corridor. Technicians were randomly assigned management areas to net; three areas were netted simultaneously each night. Upon completion of the second night of mist-netting, efforts were rotated to the remaining three areas and repeated until each management area had been netted for 12 nights. Thus, simultaneous netting effort limited sampling bias caused by movement, weather, and moonlight [32]. Net number, size, and placement were standardized when possible. Nets were $2.6 \mathrm{~m}$ in height and either six or nine 
meters in length, chosen individually based upon their ability to seal off the flight corridor. Nets were supported vertically by metal conduit pipes and were opened from ground level upwards. Nets were checked every $15 \mathrm{~min}$ for the presence of bats. Species, gender, mass, forearm length, and reproductive status were recorded. Bats were marked with uniquely numbered forearm split-bands (http://www.porzana.co.uk/bat_rings.html).

\subsection{Habitat Classification}

Previously classified Landsat 7 satellite images $\left(30 \mathrm{~m}^{2}\right.$ pixel size) from November of 2001 , the closest image available chronologically to the capture period, were used as the basis of our classification, including two footprints from GeoStor (row 24 path 35 and 36 TM data; http://www.cast.uark.edu/cast/geostor) and two footprints from the Global Landcover Facility (row 23 path 35 and 36 ETM+ data; http://www.glcf.umiacs.umd.edu). Each footprint, or surface area covered by a single satellite image, is $185 \mathrm{~km} \times 180 \mathrm{~km}$ (http://landsathandbook.gsfc.nasa.gov/handbook/ handbook_htmls/chapter6/chapter6.html). The images were stacked, so that six of the eight bands (bands one, two, three, four, five, and seven) were arranged on top of each other to represent the landscape with as much detail as possible. These four footprints were merged using the feathering technique into two separate images for breakdown into the six management area subsets. These large images were reprojected into the WGS 84 UTM Zone $15 \mathrm{~N}$ projection to make them compatible with ground control points acquired with a Garmin(C) Summit@ GPS receiver (www.garmin.com). Subsetting was accomplished by fixing a four point square area of interest over each management area, and extending the sides with the measurement tool to create a $30 \mathrm{~km} \times 30 \mathrm{~km}$ box. This subset was cut out and used as an independent image file (eight bit binary unsigned image file). The six subsets were independently classified first into 40 classes via unsupervised classification and then recoded into six major landscape classes (Mature Forest, Immature Forest, Agriculture, Water, Urban, and Bare Land). Unsupervised classification is recommended for studies of land use [23], and is especially suitable for studies of large expanses of riparian habitat (24) in an agriculture matrix [25]. Due to the homogeneous composition, even age, and similar structure of the forest fragments in question $[15,16]$, the two forest classes were combined. Recoding of the two forest classes into a single class was based upon the identification of forest patches (ground-truthing) from 60 randomly chosen ground control points (GCPs), ten within each subset, and habitat plots. We obtained habitat plot data during a forest micro-habitat study in June of 2005 [15], consisting of 120 (20 in each management area) 0.03 ha circular habitat plots randomly chosen from within a $600 \mathrm{~m}$ circular area centered on each net site (see below). Comparisons were also made to county wide aerial photos (County Mosaics; ftp files) obtained from GeoStor. While a formal analysis of classification accuracy was not conducted, all of the habitat plots $(100 \%)$ were correctly identified via ground-truthing.

\subsection{Fragmentation Analysis}

Fragmentation metrics (see Appendix A for definitions, formulas, and units) were generated using FRAGSTATS 3.3 [26] for the six $30 \times 30 \mathrm{~km}^{2}$ subsets (Figure 1, A-F), since this scale minimized overlap and pseudoreplication (Figure 1). These metrics were calculated from the two combined forest 
classes rather than from the entire landscape because of the close ecological association between the bat species in question and forests [27].

ERDAS (www.leica-geosystems.com) classification images were translated into text based ASCII files using the conversion tool in ArcView 9.1. Metrics were then calculated from the ASCII text data with FRAGSTATS utilizing mathematical algorithms, based upon individual image cell size $\left(\right.$ cell $\left.=30 \mathrm{~m}^{2}\right)$ and an eight cell neighbor rule. The eight cell neighbor rule includes both orthogonal and diagonal neighbors in the same patch [26], and was most suitable for landscape analysis of bat habitats [19]. For metrics in which total area of the image was used in the calculation (denoted by an (a) in the tables), small differences in the size of the subsets caused by the manual subset process were corrected to the target value by a translation equation (adjusted value (a) $=$ target (ha) $\div$ subset area (ha) $\times$ observed metric value (ha)). For instance, patch density (PD) measurements are derived in part by dividing the number of patches by the total area (Appendix A). Therefore, differences in total area between the subsets created by the subsetting process are critical and must be corrected before comparisons between subsets in the landscape can be made.

\subsection{Statistical Analysis}

A correlation matrix was used to reduce redundant information among landscape variables [28]. Edge density, landscape shape index, and total edge were removed from further analysis due to significant correlation with other variables which were retained (Table 1).

Simpson's Index of Diversity was calculated for bats in each of the six management areas. Linear regression was used to compare bat captures and diversity to forest fragmentation metrics including those describing area, shape, and orientation at the patch and landscape levels.

\section{Results and Discussion}

\subsection{Results}

Mist-netting yielded 304 unique bat captures (four recaptures were not considered in the analysis) from eight species after 268 net nights of effort. The most captures were obtained at Bayou De View WMA, whereas the fewest were obtained at Wapanocca NWR (Table 2). The number of species captured was greatest at the Black River NWR, with captures from eight species, including one endangered species (Myotis sodalis; [29]). Diversity ranged from 0.45 (Big Lake) to 0.83 (St. Francis Sunken Lands) (Table 2).

Of the major landscape classes, significant negative correlation was found between number of species and area covered by bare ground $(\mathrm{r}=-0.818, \mathrm{p}=0.047)$. Bat diversity was not correlated to any land class. Red bat, evening bat, southeastern myotis, Rafinesque's big-eared bat, total captures, or number of species were not significantly correlated to the coarse forest class (Total Forest Area). 
Table 1. Pearson's correlation matrix for fragmentation metrics used in the Arkansas bat fragmentation study, 2006.

\begin{tabular}{|c|c|c|c|c|c|c|c|c|c|c|c|}
\hline & NP & PD (a) & LPI (a) & ED (a) & LSI & AREA_MN (a) & Shape_MN (a) & FRAC_MN & PARA_MN (a) & CONTIG_MN & TE (a) \\
\hline NP & 1 & --- & --- & --- & --- & --- & --- & --- & --- & --- & --- \\
\hline PD (a) & $1.000 \dagger \dagger$ & 1 & --- & --- & --- & --- & --- & --- & --- & --- & --- \\
\hline LPI (a) & 0.199 & 0.203 & 1 & --- & --- & --- & --- & --- & --- & --- & --- \\
\hline ED (a) & $0.851 \dagger$ & $0.855 \dagger$ & -0.159 & 1 & --- & --- & --- & --- & --- & --- & --- \\
\hline LSI & $0.860 \dagger$ & $0.863 \dagger$ & -0.163 & $0.999 \dagger \dagger$ & 1 & --- & --- & --- & --- & --- & --- \\
\hline AREA_MN (a) & $-0.956 \dagger$ & $-0.954 \dagger$ & 0.044 & $-0.914 \dagger$ & $-0.926 \dagger$ & 1 & --- & --- & --- & --- & --- \\
\hline Shape_MN (a) & -0.043 & -0.046 & $-0.894 \dagger$ & -0.181 & 0.182 & -0.141 & 1 & --- & --- & --- & --- \\
\hline FRAC_MN & 0.678 & 0.674 & 0.307 & 0.259 & 0.274 & -0.526 & 0.022 & 1 & --- & --- & --- \\
\hline PARA_MN (a) & -0.67 & 0.668 & 0.731 & 0.282 & 0.294 & -0.543 & -0.564 & 0.595 & 1 & --- & --- \\
\hline CONTIG_MN & 0.175 & 0.179 & 0.638 & 0.102 & 0.098 & -0.146 & -0.704 & -0.21 & 0.653 & 1 & --- \\
\hline TE (a) & $0.857 \dagger$ & $0.861 \dagger$ & -0.162 & $1.000 \dagger \dagger$ & $1.000 \dagger \dagger$ & $-0.922 \dagger$ & 0.182 & 0.269 & 0.29 & 0.099 & 1 \\
\hline
\end{tabular}

Note: $\uparrow \mathrm{p}<0.05$, $\dagger \uparrow \mathrm{p}<0.001$. "a" indicates correction to target expanse by a translation equation (adjusted value (a) $=$ target (ha) $\div$ subset area (ha) $\times$ observed metric value (ha). NP = number of patches; PD = patch density; LPI = length to perimeter index; ED = edge density; LSI = landscape shape index; AREA_MN = mean patch size; Shape_MN = mean shape; FRAC_MN = mean fractal dimension index; PARA_MN = mean perimeter to area ratio; CONTIG_MN $=$ mean contagion index; $\mathrm{TE}=$ total edge. 
Table 2. Bat captures, land use, and fragmentation results from six management areas in NE AR obtained from May 31 to June 29, 2005. Area measurements (ha), landscape metrics, and distinct core areas were subsets centered on those same generated from a 2006 GIS analysis of $30 \mathrm{~km} \times 30 \mathrm{~km}$ management areas.

\begin{tabular}{|c|c|c|c|c|c|c|}
\hline Species & $\begin{array}{c}\text { Bayou De } \\
\text { View }\end{array}$ & Big Lake & $\begin{array}{l}\text { Black } \\
\text { River }\end{array}$ & $\begin{array}{l}\text { Cache } \\
\text { River }\end{array}$ & $\begin{array}{c}\text { St. Francis } \\
\text { Sunken Lands }\end{array}$ & Wapanocca \\
\hline \multicolumn{7}{|l|}{ Corynorhinus } \\
\hline rafinesquii & 42 & 0 & 6 & 4 & 14 & 1 \\
\hline Myotis austroriparius & 27 & 0 & 24 & 3 & 8 & 0 \\
\hline Lasiurus borealis & 10 & 6 & 6 & 10 & 4 & 5 \\
\hline Nyticius humeralis & 6 & 23 & 24 & 11 & 9 & 10 \\
\hline Perimyotis subflavus & 3 & 3 & 6 & 7 & 3 & 4 \\
\hline Myotis sodalis & 0 & 0 & 1 & 0 & 0 & 0 \\
\hline Myotis lucifugus & 0 & 0 & 7 & 4 & 2 & 0 \\
\hline Eptesicus fuscus & 0 & 0 & 1 & 0 & 10 & 0 \\
\hline Simpson's Diversity & 0.67 & 0.45 & 0.78 & 0.67 & 0.83 & 0.68 \\
\hline \multicolumn{7}{|c|}{ Area $\left(m^{2}\right)$} \\
\hline Bare (a) & $12,415.54$ & $25,569.28$ & $7,400.22$ & $2,898.64$ & $7,713.88$ & $14,669.54$ \\
\hline Crop (a) & $60,775.81$ & $40,167.22$ & $51,841.08$ & $71,260.02$ & $67,861.43$ & $47,626.48$ \\
\hline Forest (a) & $11,472.08$ & $8,896.94$ & $22,799.84$ & $7,961.45$ & $13,785.19$ & $22,601.42$ \\
\hline Water (a) & $3,100.31$ & $10,195.62$ & $4,385.13$ & $3,990.9$ & $3,177.31$ & $7,298.73$ \\
\hline Unidentified (a) & $2,255.83$ & $4,719.88$ & $3,379.8$ & 0.00 & 935.12 & 187.2 \\
\hline \multicolumn{7}{|c|}{ Landscape Metric } \\
\hline TA (a) & 1.00000 & 0.99502 & 0.99788 & 1.00263 & 0.99502 & 1.02652 \\
\hline PD (a) & 122.85 & 43.48 & 90.57 & 27.72 & 29.53 & 32.86 \\
\hline LPI (a) & 66.06 & 26.37 & 46.42 & 79.74 & 38.64 & 46.68 \\
\hline TE (a) & $21,113,023$ & $15,657,430$ & $17,217,786$ & $6,128,229$ & $7,362,463$ & $13,197,494$ \\
\hline $\mathrm{ED}(\mathrm{a})$ & 234.65 & 173.11 & 190.90 & 68.27 & 81.40 & 150.53 \\
\hline LSI & 176.92 & 131.80 & 144.63 & 52.00 & 62.51 & 109.55 \\
\hline CONTIG_MN & 0.18 & 0.17 & 0.20 & 0.22 & 0.13 & 0.18 \\
\hline PARA_MN (a) & $2,224.21$ & $1,062.98$ & $2,223.00$ & $2,108.16$ & $1,155.09$ & $1,054.11$ \\
\hline Area_MN (a) & 0.814 & 2.277 & 1.099 & 3.626 & 3.352 & 3.207 \\
\hline Shape_MN (a) & $41,514.20$ & $22,816.70$ & $27,610.60$ & $3,550.10$ & $5,088.10$ & $16,490.50$ \\
\hline \multicolumn{7}{|c|}{ Number of Disjunct Core Areas } \\
\hline 100 & 210 & 97 & 633 & 323 & 143 & 300 \\
\hline 200 & 48 & 34 & 93 & 50 & 84 & 84 \\
\hline 400 & 3 & 17 & $*$ & 2 & 17 & 12 \\
\hline
\end{tabular}

"a" indicates subset correction to target value by a translation equation (adjusted value (a) $=$ target (ha)/subset area (ha) $\times$ observed metric value (ha) $\times$ Indicates model failure. TA $=$ total area; $\mathrm{PD}=$ patch density; LPI = length to perimeter index; TE = total edge; $\mathrm{ED}=$ edge density; LSI= length to shape index.

Number of captures [Lasiurus borealis (Eastern red bat; LaBo)] was related to mean shape (Shape_MN) and Length to Perimeter Index (LPI, Table 3). Southeastern myotis (MyAu) and total captures (TC) were significantly related to patch density and mean patch size (Table 3). Diversity was not correlated to any of the shape indices measured. We found no significant relationship between 
number of captures and any minimum patch size area (100-, 200-, and 400-m radius) investigated with the number of disjunct core area (NDCA) metric.

Table 3. Simple regression probability (p), and $\mathrm{R}^{2}$ values for fragmentation metrics generated from a GIS analysis of six wildlife management areas and their surrounding landscapes in the northeastern Arkansas region. To save space, only those tests whose $\mathrm{p}$ values less than 0.05 are reported here.

\begin{tabular}{llcccccll}
\hline Dependant & Independent & $\mathbf{n}$ & $\mathbf{d f}$ & $\mathbf{R}^{2}$ & $\mathbf{P}$ & $\mathbf{F}$ & Regression Equation & Slope SE \\
\hline LaBo & LPI (a) & 6 & 4 & 0.698 & 0.038 & 9.25 & $\hat{\mathrm{Y}}=1.20+0.111$ LPI (a) & 0.037 \\
LaBo & Shape_MN (a) & 6 & 4 & 0.822 & 0.013 & 18.5 & $\hat{\mathrm{Y}}=117-86.6$ SHAPE_MN (a) & 19.942 \\
MyAu & PD (a) & 6 & 4 & 0.856 & 0.008 & 23.8 & $\hat{\mathrm{Y}}=-6.08+0.284$ PD (a) & 0.058 \\
MyAu & Area MN (a) & 6 & 4 & 0.727 & 0.032 & 10.65 & $\hat{Y}=30.9-8.58$ AREA_MN (a) & 7.094 \\
TC & Area MN (a) & 6 & 4 & 0.662 & 0.049 & 7.83 & $\hat{Y}=30.9-8.58$ AREA_MN (a) & 16.983 \\
TC & PD (a) & 6 & 4 & 0.801 & 0.016 & 16.1 & $\hat{Y}=16.5+0.591$ PD (a) & 0.147 \\
\hline
\end{tabular}

"a" indicates subset correction to target value by a translation equation (adjusted value (a) $=$ target (ha)/subset area (ha) $\times$ observed metric value (ha). LaBo $=$ Lasiurus borealis; $\mathrm{MyAu}=$ Myotis austroriparius, $\mathrm{TC}=$ Total Captures. LPI $=$ length to perimeter index; Shape_MN = mean shape; $\mathrm{PD}=$ patch density; Area_MN = mean patch size.

\subsection{Discussion}

The major predictors of captures were patch density and mean patch size, both supported in the literature [1,2]. Gerht and Chelsvig [1] found bat activity increased in areas with woodland fragments. This relationship is possibly driven by an increased likelihood of bats locating quality roosting sites in areas with large numbers of remnant patches [30]. However, if shear area of forest were the primary driver we should have found a significant correlation with overall forest expanse, which we did not. This was surprising but not novel, as Struebig et al. [31] found fragments with higher bat abundance than core areas but cautioned that this may not be a sustainable condition. However, these results may be indicative of habitat preference, not a lack or alternatives, as corridors between patchy areas may improve flight conditions and thus landscape exploitation [32]. It may also increase connectivity [33] with source areas and thus increase foraging opportunity. Finally, our results concur with Montiel et al. [2] in that we both found differences in total captures between different sized forest fragments. This is not unexpected, as there is a greater likelihood of a commuting animal finding the larger patches in the landscape [34].

Previous analysis of fragmentation effects on species richness at large scales has had conflicting results. Studies from Mexico [2,35] found no decrease in species richness with decreasing fragment size, in contrast to those from South America [3,4]. Montiel et al. [2] suggested that bats in the Yucatan have adapted to its naturally fragmented matrix, which is composed of forest patches isolated by flooded areas and sinkholes, whereas bats that depend on other forest types may show differing effects. Thus, our findings, in conjunction with these previous studies, hint at the existence of a latitudinal gradient in bat species richness response to fragmentation. However, caution is advised upon interpretation of these results, as species richness would be expected to increase with increasing survey effort [36,37]. 
A portion of diversity in patch arrangement can be attributed to shape complexity, mean shape (Shape_MN), which increases as shape becomes more irregular. Thus, the relationship between (Shape_MN) and Eastern red bat captures suggest this species may prefer landscapes with a large degree of diversity in patch arrangement, possibly associated with predation on insect populations that may be more numerous in edge habitats [32].

\section{Conclusions}

Forest patch density measured at the $30 \mathrm{~km} \times 30 \mathrm{~km}$ scale, with no minimum patch size limit, was the best predictor of bat captures found in this study. This result may reflect the existence of a habitat threshold not recognizable using smaller scaled sampling units [33]. If forest coverage in the overall landscape is adequate to provide bats with sufficient roosting and foraging sites, then further fragmentation should result in a loss of overall habitat and be negatively correlated with bat captures [38]. However, if habitat comprising the core matrix is of marginal quality or of limited expanse, then remaining remnant patches may represent an increase in quantity as well as improve the overall productivity of habitats and have a positive effect on relative abundance [39]. Like Gehrt and Chelsvig's [1] intensely fragmented urban landscape, the Mississippi delta is fragmented to such a degree that all forest fragments have ecological value and should be considered in the conservation plans of regional agencies.

\section{Acknowledgements}

We thank the Arkansas Game and Fish Commission for funding through the State Wildlife Grants. We thank Tanja McKay and Alan Christian for comments on early drafts of this manuscript, as well as to Bill Baker for assistance with ERDAS. We thank field technicians Stephen Brandebura and Bobby Fokidis, as well as to members of the ASU Behavioral Ecology lab and anonymous reviewers for manuscript suggestions. This research benefited from reassignment time granted to TSR from the Environmental Science program at ASU.

\section{References}

1. Gehrt, S.D.; Chelsvig, J.E. Bat activity in an urban landscape: patterns at the landscape and microhabitat scale. Ecol. Appl. 2003, 13, 939-950.

2. Montiel, S.; Estrada, A.; León, P. Bat assemblages in a naturally fragmented ecosystem in the Yucatan Peninsula, Mexico: species richness, diversity, and spatio- temporal dynamics. J. Trop. Ecol. 2006, 22, 267-276.

3. Cosson, J.F.; Pons, J.M.; Masson, D. Effects of forest fragmentation on frugivorous and nectarivorous bats in French Guiana. J. Trop. Ecol. 1999, 15, 515-534.

4. Gorresen, P.M.; Willig, M.R.; Stauss, R.E. Multivariate analysis of scale dependent associations between bats and landscape structure. Ecol. Appl. 2005, 15, 2126-2136.

5. Menzel, M.A.; Menzel, J.M.; Edwards, W.M.; Carter, T.C.; Churchill, J.B.; Kilgo, J.C. Home range and habitat use of male Rafinesque's big-eared bats (Corynorhinus rafinesquii). Amer. Midland Naturalist 2001, 145, 402-408. 
6. Menzel, M.A.; Menzel, J.M.; Carter, T.C.; Ford, W.M.; Edwards, J.W. Review of the Forest Habitat Relationships of the Indiana bat (Myotis sodalis); General Technical Report NE-284; USDA, Forest Service: Washington, DC, USA, 2001; pp. 1-21.

7. Cochran, S.M. Roosting and Habitat Use by Rafinesque's Big-Eared Bat and Other Species in a Bottomland Hardwood Forest Ecosystem; Master Thesis; Arkansas State University: Jonesboro, AR, USA, 1999.

8. Mirowsky, K.-M.; Horner, P.A.; Maxey, R.W.; Smith, S.A. Distributional records and roosts of southeastern myotis and Rafinesque's big-eared bats (Corynorhinus rafinesquii) in eastern Texas. Southwest. Naturalist 2004, 49, 294-298.

9. Wilf, L.M. The Species Composition and Habitat Use by Bat Populations in Delta National Forest, Mississippi; Master Thesis; Arkansas State University: Jonesboro, AR, USA, 2003; pp. 1-140.

10. Clark, M.K. Roosting Ecology of the Eastern Big-Eared Bat, Plecotus rafinesquii, in North Carolina; Master of Science Thesis; North Carolina State University: Raleigh, NC, USA, 1990.

11. Sealander, J.A.; Heidt, G.A. Arkansas Mammals: Their Natural History, Classification, and Distribution; The University of Arkansas Press: Fayetteville, NC, USA, 1990; pp. 1-308.

12. Hefner, J.M.; Brown, J.D. Wetland trends in the southeastern United States. Wetlands 1985, 4, 1-11.

13. Tiner, R.W. Wetland Trends of the United States: Current Status and Recent Trends; US Fish and Wildlife Service: Washington, DC, USA, 1984; pp. 1-59.

14. Twedt, D.J.; Loesch, C.R. Forest areas and distribution in the Mississippi alluvial valley: implications for breeding bird conservation. J. Biogeogr. 1999, 26, 1215-1224.

15. Medlin, R.E., Jr. Population and Distribution of the Rafinesque Big-Eared Bat and the Southeastern Myotis in the Bottomlands of Arkansas; Master Thesis; Arkansas State University: Jonesboro, AR, USA, 2007; pp. 1-145.

16. Medlin, R.E., Jr.; Risch, T.S. Habitat associations of bottomland bats, with focus on Rafinesque's big-eared bat and the southeastern myotis. Amer. Midland Naturalist 2008, 160, 400-412.

17. Fokidis, H.B.; Brandebura, S.C.; Risch, T.S. Distributions of bats in bottomland hardwood forests of the Arkansas delta region. J. Ark. Acad. Sci. 2005, 59, 51-56.

18. Medlin, R.E., Jr.; Brandebura, S.C.; Fokidis, H.B.; Risch, T.S. Distribution of Arkansas's bottomland bats. J. Ark. Acad. Sci. 2006, 60, 189-191.

19. Duchamp, J.E.; Arnett, E.B.; Larson, M.A; Swihart, R.K. Ecological considerations for landscape-level management of bats. In Bats in Forests: Conservation and Management; Lacki, M.J., Hayes, J.P., Kurta, A., Eds.; The Johns Hopkins University Press: Baltimore, MD, USA, 2006; pp. 237-261.

20. Fauth, P.T.; Gustafson, E.J.; Rabenold, K.N. Using landscape metrics to model source habitat for neotropical migrants in the midwestern U.S.. Landscape Ecol. 2000, 15, 621-631.

21. Yates, M.D.; Muzika, R.M. Effect of forest structure and fragmentation on site occupancy of bat species in Missouri Ozark forests. J. Wildlife Manage. 2006, 70, 1238-1248.

22. Hecker, K.R.; Brigham, R.M. Does moonlight change vertical stratification of activity by forest-dwelling insectivorous bats? J. Mammal. 1999, 80, 1196-1201. 
23. Pavri, F.; Aber, J.S.; Wallace, J.A.; Novak, M.C. Monitoring forest cover trends in northeastern Kansas through historical and multi-temporal satellite image analysis. Trans. Kans. Acad. Sci. 2003, 106, 2-10.

24. Everitt, J.H.; Yang, C.; Escobar, D.E.; Lonard, R.I. Reflectance characteristics and remote sensing of a riparian zone in South Texas. Southwest. Nat. 2002, 47, 433-439.

25. Fraisse, C.W.; Sudduth, K.A.; Kitchen, N.R. Delineation of site-specific management zones by unsupervised classification of topographic attributes and soil electrical conductivity. Transa. Amer Soc. Agric. Engineers 2001, 44, 155-166.

26. McGarigal, K.; Cushman, S.A.; Neel, M.C.; Ene, E. FRAGSTATS: Spatial Pattern Analysis Program for Categorical Maps; University of Massachusetts: Amherst, MA, USA, 2002; Available online: http://www.umass.edu/landeco/research/fragstats/fragstats.html (accessed on 29 September 2010).

27. Brigham, R.M. Bats in forests: What we know and what we need to learn. In Bats in Forests; Lacki, M.J., Hayes, J.P., Kurta, A., Eds.; The Johns Hopkins University Press: Baltimore, MD, USA, 2007; pp. 1-15.

28. Gaines, K.F.; Boring, C.S.; Porter, D.E. The development of a spatially explicit model to estimate radiocaesium body burdens in raccoons (Procyon lotor) for ecological risk assessment. Sci. Total Envir. 2005, 341, 15-31.

29. Brandebura, S.C.; Medlin, R.E., Jr.; Risch, T.S. New evidence for maternity colonies of the Indiana bat in the delta of Arkansas. J. Ark. Acad. Sci. 2006, 60, 169-170.

30. Duchamp, J.E; Swihart, R.K. Shifts in bat community structure related to evolved traits and features of human-altered landscapes. Landscape Ecol. 2008, 23, 849-860.

31. Struebig, M.J.; Kingston, T.; Zubaid, A.; Mohd-Adnan, A.; Rossiter, S.J. Conservation value of forest fragments to Paleotropical bats. Biol. Conserv. 2008, 10, 1016.

32. Krusic, R.A.; Yamasaki, M.; Neefus, C.D.; Pekins, P.J. Bat habitat use in White Mountain National Forest. J. Wildlife Manage. 1996, 60, 625-631.

33. Johnson, J.B.; Gates, J.E.; Ford, W.M. Distribution and activity of bats at local and landscape scales within a rural-urban gradient. Urban Ecosyst. 2008. 11, 227-242.

34. Jaenike, J.R. A steady state model of genetic polymorphism on islands. The Amer. Natur. 1973, 107, 793-795.

35. Estrada, A.; Coates-Estrada, R.; Merritt, D., Jr. Bat species richness and abundance in tropical rain forest fragments and in agricultural habitats at Los Tuxtlas, Mexico. Ecography 1993, 16, 309-318.

36. Soberon, J.M.; Llorente, J.B. The use of species accumulation functions for the prediction of species richness. Conserv. Biol. 1993, 7, 480-488.

37. Moreno, C.E; Halffter, G. Assessing the completeness of bat biodiversity inventories using species accumulation curves. J. Appl. Ecol. 2000, 37, 149-158.

38. Duchamp, J.E.; Swihart, R.K. Shifts in bat community structure related to evolved traits and features of human-altered landscapes. Landscape Ecol. 2008, 23, 849-860.

39. Gorresen, P.M.; Willig, M.R. Landscape responses of bats to habitat fragmentation in Atlantic forests of Paraguay. J. Mammal. 2004, 85, 688-697. 


\section{Appendix A}

\begin{tabular}{|c|c|c|c|}
\hline Acronym & Metric & Definition & Formula \\
\hline $\mathrm{TA}$ & Total Area & Total amount of land in class $\left(\mathrm{m}^{2}\right)$ & $\sum(\mathrm{i}=1, \mathrm{n}) \mathrm{A}$ \\
\hline $\mathrm{TE}$ & Total Edge & Total edge in a land class (m) & $\sum(\mathrm{k}=1, \mathrm{~m}) e_{\mathrm{ik}}$ \\
\hline LSI & Landscape Shape Index & A measure of class aggregation & $e_{\mathrm{i}} / \min e_{\mathrm{i}}$ \\
\hline ED & Edge Density & Edge length on a unit basis (m/ha) & $(E / \mathrm{A}) * 10,000$ \\
\hline LPI & Length to Perimeter Index & Percentage landscape occupied by a class $\left(\mathrm{m}^{2}\right)$ & $\left(\max a_{\mathrm{ij}} / \mathrm{A}\right) *(100)$ \\
\hline \multirow[t]{2}{*}{ Contig_MN } & Mean Contagion Index & \multicolumn{2}{|l|}{ A measure of connectivity } \\
\hline & \multicolumn{3}{|c|}{ 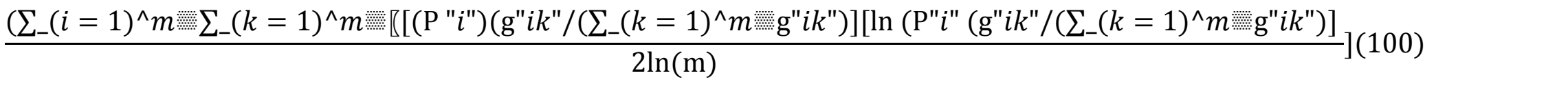 } \\
\hline Area_MN & Mean Patch Area & Sum of patch area divided by number of patches & $\mathrm{MN}=1+\frac{\sum_{i=1}^{m} \sum_{j=1}^{\mathrm{n}} \mathrm{X}_{\mathrm{ij}}}{\mathrm{N}}$ \\
\hline Frac_MN & Mean Fractal Dimension Index & Shape complexity that relates perimeter to area & $(2 *(\ln (0.25 \mathrm{pij}))) / \ln (\mathrm{aij})$ \\
\hline Para_MN & Mean Perimeter to Area RatioA measure of shape complexity & A measure of shape complexity & $\mathrm{p}_{\mathrm{ij}} / \mathrm{a}_{\mathrm{ij}}$ \\
\hline Shape_MN & Mean Shape & Increases without limit as shape becomes irregular & $p_{\mathrm{ij}} / \min p_{\mathrm{ij}}$ \\
\hline PD & Patch Density & The number of patches in a landscape (N/100 ha) & $\left(\mathrm{n}_{\mathrm{i}} / \mathrm{A}\right)^{*}(10,000)(100)$ \\
\hline NDCA & Number of Disjunct Core Areas & Number of core areas based upon edge depth & $\sum(\mathrm{j}=1, \mathrm{n}) \mathrm{Nij}^{\mathrm{c}}$ \\
\hline
\end{tabular}

* All metric definitions come from Fragstats 3.3 help index; McGarigal et al. 2002.

(C) 2010 by the authors; licensee MDPI, Basel, Switzerland. This article is an open access article distributed under the terms and conditions of the Creative Commons Attribution license (http://creativecommons.org/licenses/by/3.0/). 